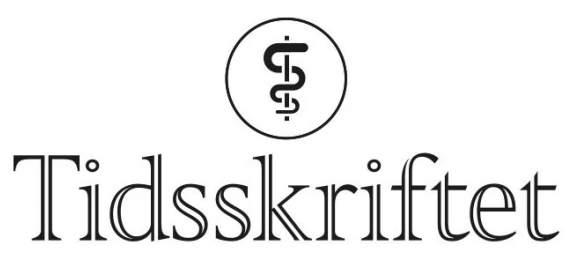

DEN NORSKE LEGEFORENING

\title{
Dag Sørskaar
}

MINNEORD

PAUL LINNESTAD

Dag Sørskaar ble født 23. mars 1938 og døde 8. august 2020. Han ble cand.med. i 1967, spesialist i barnesykdommer i 1978 og dr.med. i 1990. Hans siste stilling var som overlege i barnerevmatologi på Rikshospitalet.

Da vi møttes på legestudiet i Oslo i 196o, var Dag allerede verdensvant. Han hadde vært ett år i St. Moritz, trukket dit av medisinen - og også av vintersporten, for Dag var en allsidig idrettsentusiast. Det mest konkrete referatet han ga fra livet i Sveits, var et løypeskilt: «nur für sehr geübte Skiläufer». I undervisningen var det nok dårligere glid. Forelesninger der man verken kunne se eller høre taleren, var ikke noen pedagogisk vinner for Dag.

Første studieår leste vi på Deichman sammen med slitne hjemløse. Andre året fikk vi faste leseplasser. Da Dag jaget bort en førsteårsstudent, som spurte hvorfor nettopp Dag skulle ha plass, var svaret: «Det er best slik». Dag var rett på sak med meget klare oppfatninger. Vi ante nok et visst misantropisk trekk, og en gang i studentmessa sa han at det manglet en paragraf i FNs menneskerettighetserklæring: retten til å mislike hvem man vil. Dag benyttet seg av denne retten, men langt hyppigere av retten til å muntre opp sine omgivelser.

Dag hadde «hug til bokji», men syntes lærebøkene kunne bli vel tykke. Hos Norli bemerket han, da bokhandleren viste fram en fyldig bok, at han ikke var ute etter «bibliofilutgaven» Dag hadde et lidenskapelig forhold til aviser, nesten en tvangsmessig kjærlighet, som krevde at alle de avisene som ble brakt inn i huset, skulle leses. Vi husker høye stabler med ulest vare. Fordelen med lagringen var at avisene - lik årgangsvin - ble foredlet, slik at de i neste omgang inspirerte oss til lange og fornøyelige diskusjoner. Studenten Dag holdt seg til Morgenbladet. Legen Dag, muligens modnet på Akademiska sjukhuset i Uppsala, sverget til svenske Dagens Nyheter, «verdens beste avis».

Vivi og jeg har satt stor pris på det lange og gode vennskapet med Dag og Kari, med mye hygge og latter. Våre atspredelser har vært fine, og vi har hatt stor glede av våre ikke altfor ærgjerrige dagsturer, ofte med et historisk eller kunstnerisk mål.

De siste årene med sykdom har vi dessverre mistet kontakten med Dag. Denne sorgen skal ikke skygge for gleden. Nå er det de hyggelige minnene vi skal verne om. Det er de som skal hjelpe oss å mestre sorgen.

Våre tanker går til deg, Kari, og til Erlend, Rannveig og Frode. 
Publisert: 28. september 2020. Tidsskr Nor Legeforen. DOI: 10.4045/tidsskr.20.069o

(C) Tidsskrift for Den norske legeforening 2023. Lastet ned fra tidsskriftet.no 26. april 2023. 